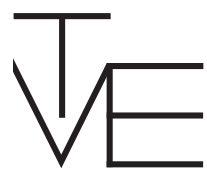

\title{
Microfinance institutions' failure to address poverty: A narrative critical literature review
}

\author{
Sigurdur Gudjonsson ${ }^{1}$
}

\begin{abstract}
This critical literature review begins by giving a short introduction to the microfinance industry. Microfinance institutions (MFIs) are explained and an account is given of their dual performance goals of financial performance ('financial sustainability') and social performance ('outreach'). While MFIs' social performance is directly aimed at poverty reduction, it is noteworthy that often they fail to address poverty (i.e., they fail to deliver outreach). The aim of the paper is to answer the following research question: Why have microfinance institutions (MFIs) failed to address poverty? In order to establish the reason, the first step is to look at how the MFIs are managed and controlled, i.e. to examine MFIs' corporate governance literature. This critical literature review was conducted using systematic on-line searches in the databases Scopus and Web of Knowledge; the main key words used were microfinance, gender, corporate governance and performance. The unconvincing nature of the findings of a review of the corporate governance literature suggests that another factor should be taken into consideration: that of gender; after all, MFIs are mainly used by women. The findings from reviewing the microfinance literature suggests that microfinance gender literature may explain why MFIs have not adequately addressed poverty, but this literature consists of a few studies only and further studies are needed. The literature on gender in general is more substantial, however. Some
\end{abstract}

1 Sigurdur Gudjonsson is an Adjunct at the University of Akureyri. Email: sigurdurg@ unak.is 
account of it will be given in this literature review. The findings of this literature review should benefit policymakers on the one hand, who are in a position to advance gender equality, while on the other hand it should be of use to academics, who can research MFIs in relation to gender; further studies of gender in MFIs are encouraged.

JEL: M1; M14

Keywords: Microfinance; gender; women; corporate governance; dual performance; outreach; financial sustainability.

\section{Introduction}

The aim of this paper is to answer the following research question: Why have microfinance institutions (MFIs) failed to address poverty? The paper begins with a description of the microfinance industry. A formal definition of microfinance is provided and MFIs' potential importance in addressing market failure will be discussed. Market failure takes place where the poor are kept without financial inclusion and continue to remain in poverty (Armendáriz and Morduch, 2007). Group lending and peer monitoring are explained. An account will be given of MFIs' dual performance goals of providing good social performance (here called 'outreach') and sufficient financial performance, (here called 'financial sustainability'; Armendáriz and Morduch, 2007). Financial performance is called 'financial sustainability' rather than profit in microfinance literature since profit is usually used for organizations where the stress is on profit maximization. 'Financial sustainability' is used as meaning financial performance that is sufficient to ensure that the organization will survive in the long run. A brief history of the industry is given, followed by an account of the location of MFIs and current state of affairs.

As the paper addresses performance of MFIs, a closer look at outreach and financial sustainability is essential. MFIs are intended to supply a deficiency of the market, eventually resulting in poverty reduction. Therefore particular importance is attached to MFIs' social performance or outreach. The research method for this narrative critical literature review will be discussed in Section 3, Research method.

The findings from reviewing the microfinance literature suggest that microfinance gender literature may explain why MFIs have not adequately addressed poverty. However, only a few studies have been done and more are needed. The literature of gender in general is more substantial. Some account of it will be given in this review.

The paper is structured as follows. Microfinance institutions (MFIs) will be defined, with an account of their history and the current situation of the microfinance industry and its dual goals. The methodology part is placed before the review of microfinance corporate governance literature, which is 
followed by a review of gender-related microfinance literature. A short review of the literature on gender in general precedes the conclusion.

\section{The microfinance industry: institutions and goals}

\subsection{History and current standing}

Poverty is not only a humanitarian issue. It is also a threat to any society's stability and therefore addressing poverty in the aftermath of the Second World War was a priority (Adams et al., 1984). Development programs were created, often in the form of governmental or institutionally subsidized loans to the poor. However, low repayment rates, unprofitable investments and corruption led to somewhat disappointing results (Adams et al., 1984).

A more successful attempt to address people's lack of access to capital than by means of the traditional development programs mentioned above came with the introduction of the microfinance solution in the 1970s (Yunus, 2007). An early pioneer in the microfinance field was Muhammad Yunus, founder of the Garmeen Bank of Bangladesh and 2006 Nobel Peace Prize Laureate. He began to lend small amounts of his own money to women so they could begin small-scale entrepreneurial activities. These women did not provide collateral (Yunus, 2007). In substitute for collateral, Yunus used the borrower's network connections to ensure repayment, i.e. group lending with joint liability (Yunus, 2007). Garmeen's lending method also provided new dynamic incentives to encourage full repayment. If all of the borrowers repaid, they could obtain higher amounts next time they required a loan. Furthermore, in order to minimize risk, a very frequent repayment system was introduced. The method was fairly successful and allowed a certain number of poor women to work their way out of poverty while repaying their loans.

From its emergence in the 1970s, the microfinance industry has grown rapidly, reaching more than 13 million clients at the turn of this century. Currently, it is estimated that more than 200 million borrowers are now involved in the system (Maes and Reed, 2012). More than half of the borrowers are women and two thirds of the microfinance borrowers are 'very poor,' i.e., they live on a less than USD 1.25 per day. The poverty of the female borrowers is a pertinent issue since more than 80 per cent of the very poor are women (Maes and Reed, 2012).

Microfinance is a growing industry; in some countries it is growing at more than 20 per cent annually (Lascelles and Mendelson, 2011). However, despite this growth and coverage, currently only half of the world's seven billion people receive any kind of financial inclusions (World Bank, 2012).

Microfinance institutions are unequally distributed around the globe. More than 95 per cent are in the developing world (Maes and Reed, 2012). 
A little less than half of all these institutions are in the Asia-Pacific region, roughly a quarter are in the Sub-Saharan region and a little under 20 per cent are located in Latin America (Maes and Reed, 2012). Most of the biggest institutions are on the Indian subcontinent (Maes and Reed, 2012).

\subsection{Microfinance institutions (MFIs)}

Microfinance institutions (MFIs) are entities intended to supply a deficiency in the market. For traditional lending institutions such as banks, the loans sought by potential borrowers are too small for them to break even. MFIs, however, do not have to collect costly information (screening of the individual's ability to pay the loan back) on borrowers. Furthermore, the borrowers are usually poor women, often without financial inclusion and lacking in collateral assets (Armendáriz and Morduch, 2007). MFIs are set up to solve this issue by providing the poor with loans. The cycle of poverty can be broken and the poor can be brought into the formal economy, thereby increasing financial inclusion.

A formal definition of the term 'microfinance' is provided by Karlan and Goldberg (2011) page 20: 'Broadly speaking, microfinance for loans (i.e., microcredit) is the provision of small-scale financial services to people who lack access to traditional banking service. The term microfinance usually implies very small loans to low-income clients for self-employment, often with the simultaneous collection of small amount of savings.' In addition, Karlan and Goldberg (2011) name key characteristics often associated with microfinance, such as small transactions, loans for entrepreneurial activity, loans without collateral, group lending, low-income clients who are often women, a simple application process, provision of services in underserved communities and market-level interest rates.

\subsection{The dual performance goals - outreach and financial sustainability}

What distinguishes microfinance institutions from financial institutions is their dual goals: outreach and financial sustainability. These dual goals differ significantly from the primary goal of banks - financial performance - as well as from those of traditional development organizations, as those institutions do not necessarily have to attain financial sustainability to survive since they obtain their funding from other sources such as governments or other state-funded organizations (Armendáriz and Morduch, 2007).

Microfinance institutions are expected to perform well both financially and socially. Their financial performance ('financial sustainability') is usually assessed in microfinance literature in terms of classical financial performance indicators such as Return on Assets (ROA) or Return on Equity (ROE) (Armendáriz and Morduch, 2007). The institutions' social performance ('outreach') is usually assessed either in terms of its depth or its breadth (Ar- 
mendáriz and Morduch, 2007). Depth of outreach is the average loan balance per borrower divided by GNI per capita (i.e. gross national income divided by population of each country). The lower the outreach number, the deeper or better is the outreach. This measurement of outreach is common in microfinance literature: see, for example, Quayes (2012), Mersland and Strom (2009) and Hartarska (2005). Breadth of outreach is simply the number of MFIs' borrowers. This measurement approach to outreach does not distinguish between the poverty levels of the borrowers. In this paper, when outreach is referred to, it is depth of outreach.

Although both outreach and financial sustainability are important for the MFIs, it is the outreach aspect that makes MFIs so unique (Strom et al., 2014). With better outreach, the needs of the poor are addressed, while they are brought out of the cycle of poverty stemming from imperfect market conditions. Arguably, therefore, outreach is the most important mission of MFIs (Strom et al., 2014).

Since a deeper understanding of an organization's performance (usually in terms of financial performance) involves a knowledge of the organization's corporate governance, the next logical step is to examine how corporate governance shapes MFIs' performance. The starting point is a brief review of corporate governance literature, followed by a review of the literature that deals with MFIs and corporate governance. Although understanding of organizational performance is usually aimed at financial performance, our first step is to take a look at MFIs' performance in terms of traditional corporate governance issues such as agency issues via the ownership (the board) of the organization and those who control the institutions on a day-to-day basis (managers, CEOs). This is done even though the focus is on social performance (outreach), since organizations with social objectives will also benefit from how they are governed, i.e., the corporate governance literature also applies to organizations with social objectives (Fama and Jensen, 1983).

\section{Research method}

Before the corporate governance literature is reviewed, the research method used for this critical review will be discussed. According Hart (2001), a critical literature review is a review of already published and unpublished material (Hart, 2001). Jesson and Lacey (2006) define a critical review more narrowly, as they only include published material. In this paper, a survey of properly conducted reviews of literature in high-ranking journals from the Scopus and Web of Knowledge databases was carried out.

Regarding details of how this critical literature review was conducted, the internet is becoming a more frequently used means of information gathering in work such as critical literature reviews (Jesson and Lacey, 2006), and this was the case here. The keywords used were microfinance, corpo- 
rate governance, gender and performance. These are further listed in a table below. This review consists of a review of published papers on MFIs that takes into account corporate governance issues (and of the limited number of published works on MFIs and gender). Jesson and Lacey (2006) present two main methodology types that are often used when critical literature reviews are conducted: the narrative critical review, i.e. a narrative account of already available information, and a systematic review or meta-analysis, which is a method or a type of quasi-experiment in itself where the results from already published literature are described. This literature review is of the former type.

The motivation or the reason why this critical literature review was conducted was to shed light on the current state of knowledge of the microfinance literature in relation to why MFIs have failed to address poverty. The literature on how MFIs are run, i.e., the corporate governance literature in relation to MFIs, was therefore reviewed but the findings from this critical literature review were far from consistent, as will be discussed in the next section.

\begin{abstract}
Topics and search terms: Microfinance + failure to reduce poverty. The review was based on a selection of studies of microfinance topics in accepted academic journals via two large databases: Web of Knowledge and Scopus. The key words used in searches were: microfinance + corporate governance + performance + gender.
\end{abstract}

Although the papers reviewed here were found in the two databases mentioned above, this search covered papers which varied in terms of scope and quality and were presented in various academic journals, some of high quality, others less so. It is possible that a high-quality paper with important findings could be found by other means. The review therefore has its limitations in this regard. Furthermore, this critical literature review is what Jesson and Lacey (2006) call a narrative critical literature review; but it would be interesting to see results of a systematic critical review or meta-analysis and such a study is therefore called for.

\title{
4 The microfinance industry's inconsistent performance solved by women
}

\subsection{Internal corporate governance - Microfinance industry}

Literature on corporate governance can be traced back to Jensen and Meckling's (1976) seminal agency theory, where the agent (usually the manager) does not act wholly in the interest of the owner (often called the principal), but also out of self-interest. The agent may choose to focus on activities that 
may lead to the total value of the firm becoming less than it would be if the manager were the sole owner of the firm. There is therefore an agency cost, and hence, the manager's interest clashes with the owner's interest. In addition, the principal does not have all the information about what the agent is doing (Jensen and Meckling, 1976).

Despite these issues, the separation of ownership and control is economically efficient, as Eisenhardt (1985) explains. If the agent's performance is monitored, evaluated and rewarded, all of which can be done by keeping a well-structured and independent board, having independent external directors, separating the positions of board chair and CEO, imposing age and term limits on directors and creating incentives for managers, the agent is more likely to manage the organization in line with the owners' objectives, which should be the maximization of the organization's value. Furthermore, the board members can replace members of the management team if necessary (Williamson, 1985).

While traditional corporate governance literature is usually concerned with institutions that have solely financial performance goals, according to Fama and Jensen (1983), institutions with social objectives can also benefit from this body of literature. While non-profit organizations may differ from for-profit organizations, in the sense that the former do not have owners who are concerned with their profit maximization; nevertheless the agency issue between the management, who take the decisions, and the agent still remains (Fama and Jensen, 1983). In this sense, corporate governance mechanisms and principles should also be of relevance for organizations that have social goals, such as MFIs.

Although it may be possible to use traditional corporate governance ideology in order to account for both financial performance and social performance, some challenges remain to be dealt with. Corporate governance literature struggles to explain the reason behind the performance of organizations in general (Dalton et al., 1998; Aguilera and Jackson, 2003) and of MFIs in particular (Mersland and Strom, 2009).

While the literature of corporate governance evolved in the late 1970s and developed further throughout the 1980s, the empirical results are anything but consistent (Dalton et al., 1998). In a meta-analysis carried out by Dalton et al., (1998) the authors found no correlation between the board's independence and performance. In another meta-analysis, Daily, Dalton and Channelled (2003) did not find any correlation between independent board directors, the duality of the CEO and the board, and the firm's financial performance. In fact, the authors state that alternative theories or models are needed in order to find what within corporate governance may possibly explain a firm's performance (Daily et al., 2003).

The reason why corporate governance fails to explain organizational per- 
formance may, according to Aguilera and Jackson (2003), lie in the shortcomings of the over-emphasis on the agency theory, which fails to take a look at interdependencies among the stakeholders of the organization. Renneboog, Horst and Zhang (2008) argue along similar lines, suggesting that corporate governance should be broader and be termed 'stakeholder governance'. This alternative governance would still include traditional corporate governance issues but would also take into account issues related to other stakeholders.

A review of literature on corporate governance vis-à-vis the microfinance industry is provided below. As the review will demonstrate, the conclusions of the current literature are vague, inconsistent and mixed.

Campion (1998) undertook a survey in which questionnaires were sent to several MFIs in order to collect data and draw conclusions, with the aim of making suggestions for the improvement of corporate governance of these institutions. The findings suggested that the board and the management were, in general, working closely together (Campion, 1998). However there were few board meetings and MFIs were often dependent on one key powerful person within the institutions, usually the managing director or the chairman of the board. Furthermore, board members' selection was not formal and members were often untrained. There were also many internal board members, casting doubt on their independence, especially when it came to matters of accountability, conflict of interest and innovation (Campion, 1998). Shortly thereafter, conscious of the MFIs' corporate governance shortcomings, Labie (2001) called for an improvement in the relationship between board and managers and raised the issue of lack of independence, which is often an issue for MFIs.

Rock, Otero and Saltzman (1998) presented a report suggesting that the traditional board structures with good corporate governance should be implemented in MFIs. These structures include the separation of the board chairman and the CEO, the role of the chairman of the board in relation to other board members and the use of board committees. Rock et al. (1998) claimed that the microfinance industry worked along lines similar to those of other industries, and therefore traditional corporate governance should be directly applicable to MFIs. Campion (1998) concurred with this view as he found that the governance practice of non-profit and for-profit MFIs had more similarities than differences.

The early microfinance literature on corporate governance was followed by empirical studies undertaken particularly on corporate governance issues in the microfinance industry. The potential benefits of an independent board were addressed in one of the earliest studies that examined the relationship between the corporate governance mechanism and performance at microfinance institutions (Hartarska, 2005). Hartarska (2005) found a trade-off between the two microfinance performances, outreach and financial sustaina- 
bility, which was directly related to stakeholders' representation on the board, hence illustrating the value of an independent board with limited employee participation. Several studies followed which showed similar results. Notable studies include those by Kyereboah-Coleman and Osei (2008), Bassem (2009) and Mersland and Strom (2009). In a more recent study, which takes into account more up-to-date data and is perhaps more accurate in relation to the current state of the microfinance industry, Hartarska and Mersland (2012) stress on the basis of their findings that MFIs with a board containing a larger proportion of insiders are considerably less efficient than those with many independent board members.

Kyereboah-Coleman and Osei (2008) and also Hartarska (2005) found if the CEO and chairman were the same person (called 'duality'), MFIs were less efficient. While the effect of board independence and duality appears to be firmly established, such is not as obvious regarding size of the boards of microfinance institutions. Kyereboah-Coleman and Osei (2008) argued that board size was positively related to financial performance and profitability but negatively related to outreach. Hartarksa and Mersland (2012), however, claimed that boards with up to nine members can retain their efficiency, but thereafter it declines.

There are also other issues in MFIs' organizational framework within corporate governance that are shown to affect performance, notably their managers' experience. As Hartarska (2005) pointed out, experience is positively related to MFIs' efficiency. But while managers' experience may improve MFIs' efficiency, such may not be the case if the power of the CEO or other managers is examined. Indeed, Galema, Lensink and Mersland (2012) showed that powerful CEOs with more decision-making powers than CEOs usually have, could make decisions which increased the MFIs' risk exposure. These risk-driven decisions were, according to the authors, causing worse financial performance than at institutions that were run by CEOs who were not highly risk-seeking (Galema et al., 2012).

Significantly, the findings of Galema et al. (2012) appear to be particularly true for one type of MFI: the non-governmental organization (NGO). Mersland (2008) observed that most MFIs are either NGOs or cooperatives (COOPs), while policy papers advocate shareholder firms (SHFs). Mersland and Strom (2008) found the difference between shareholder-owned MFIs and NGOs to be very small and argued that there was no logical reason to transform NGOs into shareholder firms. The authors published another paper in which they addressed non-profit microfinance organizations and shareholder microfinance institutions and their effect on financial performance and social performance; they found no difference (Mersland and Strom, 2009).

Other research has been carried out on different types of MFIs. For example, Perilleux, Hudon and Bloy (2012) found that MFIs allocated their surplus 
differently depending on their ownership structure. Both non-profit MFIs and shareholder MFIs kept their surplus within the institutions and used it for self-financing margin rather than transferring it to employees or clients. Cooperatives, on the other hand, distributed their margin to their clients (Perilleux et al., 2012).

As for MFIs' performance in relation to their size, Hudon (2010) claimed that well-managed MFIs were often larger than other MFIs. However, Guierrez-Goiria and Goitisolo (2011) did not find any relationship between size, either as regards profitability or social performance.

The age of MFIs may also be a decisive factor for outreach depth, as Makame (2006) pointed out. However, Hudon (2010) found that well-managed MFIs may not necessarily be older. It is important to note here that MFIs may have very different goals for their institutions to undertake, for example some are only focused on reaching out to the very poor; some may be heavily subsidized and therefore their financial performance will not improve with their age, simply because it is not meant to do so.

Several other corporate governance issues have been focused upon in microfinance literature. Bonuses to managers have not been shown to accompany better financial performance or better social performance (Hartarksa, 2005; Bassem, 2009). Transparency has had a good effect on MFIs' performance, as Augustine (2012) claims. The same is argued by Quayes (2012) who found that MFIs with a high level of public disclosure tend to perform better both financially and socially.

\subsection{External corporate governance - the microfinance industry}

To turn to external governance, external corporate governance issues such as the competition between MFIs for clients show mixed results (Olivares-Polanco, 2005) as will be discussed below. In an early study, Olivares-Polanco (2005) claims that competition in the market tends to lead to larger loan sizes and shallower outreach, and that in these cases, the poorest borrowers are simply dropped from the microfinance lending portfolio (Olivares-Polanco, 2005). These findings are contradicted by a finding by Hartarska and Mersland, (2012) who observed that competition had no effect on MFIs' performance. D'Espallier and Vanroose (2013) found MFIs to reach more clients and were also more profitable in countries where access to traditional financial system was limited. In contrast, in countries where there was already an established banking system, the existing banks were in competition with the microfinance institutions, which pushed them down-market towards the poorest customers, hence deepening the outreach, i.e., greater competition pushes MFIs down towards the poorest and provides them with loans (D'Espallier and Vanroose, 2013).

The findings of Assefa, Hermes and Meesters (2013) were similar. They 
discovered empirical evidence that competition among MFIs deepened their outreach (Assefa et al., 2013). Cull et al. (2007) also stated that where there was competition in the market, MFIs were pushed toward the poorest borrowers and the outreach deepened. This appeared to be particularly true for microfinance banks that relied on commercial funding and those that used traditional bilateral lending contracts instead of group lending (Cull et al., 2007).

Regulation is another external corporate governance aspect that has been touched upon. The earliest research on regulations and their effect on MFIs performances, such as that conducted by Hartarska and Nadolnyak (2007) and Mersland and Strom (2009), showed no effect. However, a more recent study by Hartarska and Mersland (2012) suggested that the relationship between regulation and performance may be more complicated. They found weak support for MFIs in countries with mature regulatory environments: there, MFIs reached fewer clients since in these countries poor clients did not need to go to MFIs: instead they were more likely to be able to go to a bank or other traditional financial institution. But MFIs regulated by an independent banking authority provided better efficiency (Hartarska and Mersland, 2012).

Internationalization may also play a role in MFIs' performance. Vanroose (2008) argued that the microfinance sector was better placed in the 'better-off part' of the developing world, i.e., in those countries that were not among the poorest in the world but were still considerably poorer than rich developed countries. Those better-off countries in the developing world are countries that have considerably fewer people living in absolute poverty than the poorest countries in the world where such living conditions are more common. Living on less than USD 1.25 per day is usually defined as absolute poverty (Maes and Reed, 2012). Furthermore, Vanroose (2008) argues that MFIs reach more clients in countries where international support is present and strong (Vanroose, 2008). Ahlin, Lin and Maio (2011) also argued that country issues mattered, for example countries that had stronger economic growth were a better environment for MFIs to operate in in terms of better repayment rates and also countries with more developed financial systems were better environments for MFIs in the sense that they had lower default rates, lower operating costs and were able to charge lower interest rates. However, countries that already had relatively developed manufacturing systems and higher workforce participation tended to have less growth in outreach (Ahlin et al., 2011). A noteworthy finding about internationalization is provided by Mersland and Strom (2011), who found that it directly affected MFIs' social performance for the better.

Credit risk and credit rating are other factors that have been examined. Ayayi (2012) argued that low credit risk is a direct consequence of good im- 
plementation of corporate governance practices, while Beisland and Mersland (2012) argued that ratings of MFIs are mostly driven by these institutions' size, profitability and risk exposure.

It is important to note, however, that external corporate governance issues at microfinance institutions are challenging. Hartarska (2005) claims that external governance issues are unlikely to have a great effect on microfinance performances, both as regards their financial and social objectives. Adams and Mehran (2012) also claimed that since MFIs were very special institutions, with their dual performance goals of outreach and financial sustainability, their governance structure may as well appear to be very industry-specific for the microfinance industry.

Corporate governance literature is mixed where MFIs are concerned (Mersland, 2011). Indeed, the review of the corporate governance and microfinance literature above reveals the findings to be anything but consistent, both for regulation and management. For regulation, Hudon (2010) found that well-regulated MFIs performed well, but Hartarska and Mersland, (2012) found such institutions were unable to reach many clients. Hartarska (2005) found a limited effect of regulation on performance, while Mersland and Strom (2009) found no effect whatsoever. As for the management structure, Hartarksa and Strom (2012) found MFIs in which duality was found (where the chairman of the board is also the CEO), to be less efficient, but Kyereboah-Coleman and Osei, (2008) found such MFIs to be more profitable. Mersland and Strom (2009) found MFIs with duality able to reach to more borrowers. Finally, managers' level of experience tended to have no effect on MFIs' performance according to Hudon (2010), but according to Olivares-Polanco (2005), this factor has a positive effect. In fact, such is the diversity of conclusions that Mersland and Strom (2009) stated, in a relatively early paper on microfinance and corporate governance, that the industry would require other approaches in order to explain corporate governance and performance in MFIs.

As shown from the literature reviewed above, the conclusions of the corporate governance literature on performance at organizations in general, and for MFIs in particular, is mixed. A different approach, therefore, has to be taken in order to account for good performances in MFIs.

Why are these results inconsistent? Why do MFIs show mixed results when outreach is concerned so that overall, MFIs do not seems to be reaching out to the poor properly? The reason may be found by looking at gender, as those individuals who use these institutions are often women.

Indeed, Strom et al. (2014) examined gender in microfinance. They argued that gender, and most notably the presence of a female CEO, could explain some of MFIs' financial performance. Microfinance gender-specific issues are noteworthy, particularly since the microfinance industry is female-specific (Strom et al., 2014). The gender aspect in microfinance literature will be ad- 
dressed in the following section to see how it could further advance the literature of how MFIs are governed.

\subsection{Gender in the microfinance literature}

The conclusions of the literature on corporate governance and on gender in general are, again, mixed (Bohren and Strom, 2010; Nielsen and Huse, 2010; and Dalton et al., 1998). On the one hand, Carter, Simkins and Simpson (2003), Erhard, Werbel and Shrader (2003), and Campbell and Mínguez-Vera (2008) found that gender diversity in the board had a positive effect on organizational performance and Krishnan and Park (2005) and Shrader, Blackburn and Iles (1997) found so for management. On the other hand, Adams and Ferreira (2009) and Smith, Smith and Verner (2006) found a negative relationship, while Chapple and Humphrey (2014) found a weak negative relationship between gender diversity and organizational performance. Furthermore, Dwyer et al. (2003) and Carter et al. (2010) found no relationship whatsoever between gender and organizational performance.

However, women may in general often help and support each other (Eagly, 1987), which might result in better social performance and eventually reduce poverty. That can be argued by examining the social role theory of gender differences and similarities presented by Eagly (1987), who argued that males and females behave in a 'stereotypical' manner when they follow their social roles. Eagly, Wood, and Dieman (2000) defined these roles as shared beliefs of females or males that applies to them and their socially identified gender and these social roles are observed by each gender in their personal and professional environment. According to these roles, women were found to be more concerned with others, more friendly, altruistic and emotionally expressive, while men were found to be more agentic, independent and competent in decision-making within organizations (Eagly and Wood, 1991). Furthermore, women tend to be more considerate, helpful, friendly, open and concerned for the welfare of others, i.e. interpersonally-oriented while men tend to be more task-oriented (Eagly and Johannesen-Schmidt, 2001).

Indeed, a new study on microfinance institutions in which women are influential does suggest that such institutions provide better outreach to the poor (Mengoli, Odorici and Gudjonsson, 2017). As for internal corporate governance issues in MFIs, such as in internal monitoring activities, then the size of microfinance loans to women is usually smaller, D'Espallier et al., (2013) observed, resulting in deeper outreach towards women. Agier and Szafarz (2013) argued that although loan approval rates were gender-neutral, the loan size to female borrowers on the other hand was lower. Similar results had been found earlier by Omri and Chkoundali (2011). Different types of MFIs appear to play a role, as argued by D'Espallier, Guering and Mersland (2013); MFIs focusing on women are usually NGOs. 
As for external corporate governance issues such as the composition and gender of groups of stakeholders of MFIs, increasing competition in the microfinance market pushes MFIs to loan increasingly to poorer borrowers and to women; hence, increasing competition deepens outreach and increases the number of female borrowers (D'Espallier et al., 2013). Women are also associated with better repayment, particularly to NGOs (D'Espallier et al., 2013) and internationalization is associated with more female borrowers (D'Espallier et al., 2013). Finally, MFIs receiving international subsidies tend to target female customers in larger number than other MFIs (Mersland and Urgeghe, 2013).

Women borrowers are also believed to be associated with better outreach (Hermes et al., 2011). The external environment may also favour women, resulting in better outreach. Cull, Demirguc-Kunt and Moduch (2013), found that greater banking competition led to greater outreach, in particular to women.

Studies of microfinance might benefit from attention to the gender study framework in general. While it would be impossible and unfocused to review all such studies in this critical literature review, some recent aspects will be introduced in the following sub-section.

\subsection{Relevance of gender studies in general for microfinance studies}

In this section, the gender study framework is used in more general terms in order to try to understand what direction microfinance research might take. Few aspects will be looked into, but it is important to stress that this gender literature review is by no means comprehensive; rather, it should be used as an idea of how future microfinance studies in relation to gender may be moved forward.

Gender-studies literature indicates that females are more risk-averse than males (Ecel et al., 2008; Saren and Wieland, 2016). The reason for this may lie in cultural issues, since in western culture risk-taking is seen as a masculine characteristic (Nelson et al., 2015). Other branches of studies suggest that it has biological explanations (Coates et al., 2010): the amount of testosterone is an effective variable causing more risk-taking behaviour among males and less by females (Sapienza, Zingales and Maestripieri, 2009). The finding that females are less inclined to risk-taking than males has been further established in psychological research (Barber et al., 2001), laboratory experiments (Powell and Ansic, 1997) and carefully conducted surveys (Dohmen, 2011). Microfinance studies would benefit from research related to females being more risk-averse than males: this could possibly explain why MFIs have not reached the poor as they should have.

Demographic issues may be explanatory. For example, Yao and Hanna 
(2005) found unmarried males to be the most risk-seeking, then married males, followed by unmarried females and finally married females. Hartog et al. (2012) found entrepreneurs to be more risk-seeking than company employees; civil servants were more risk-averse than private-sector employees and finally females were less prone to risk than males (Hartog et al., 2012). Khan et al. (2007) tried to seek out why white males appear to be less riskaverse than racial minorities and females, in fact such is the fixation of females being more risk-averse than males that Olsen et al. (2001) found that even if females were trained investors, this had no impact on research outcomes: female trained investors were still more risk-averse than male trained investors (Olsen et al., 2001). It would certainly be interesting to see how gender differences as established in these studies relate to performance by MFIs.

Studying other aspects of the influence of gender would also benefit microfinance studies. In an interesting study, Marmaros and Sacerdote (2002) found that male students' networks were more closely connected, while female students were not as well connected. The organization is, according to Acker and Joan (1990) a masculine phenomenon. How this all relates to MFIs would be worth studying: if females are less connected than males in MFIs, this could potentially explain different financial and social performances of these institutions. Finally, gender and microfinance studies might benefit from further research into gender and tokenism, originally introduced by Kanter (1977).

While further review of gender and its possible effect will not be undertaken here, it is important to note that scholars engaged in microfinance studies, such as Mersland and Labie (2011) and Hartarska and Mersland, (2012) have called for specific approaches at microfinance institutions. The adoption of a particular approach in the microfinance industry, such as one that takes particular account of gender issues, could explain how MFIs attain their performance goals. Therefore, instead of relying on traditional corporate governance approaches to performance, the particular gender issues of the microfinance industry should be used to explain the performance of the MFIs. This should be done by further researching the gender literature. Strom et al. (2014) found that gender had little effect on financial performance. The next logical step would be to undertake similar research where the focus would be on the social performance, outreach and therefore poverty reduction. Further research on microfinance institutions in relation to the findings of gender literature is desirable. 


\section{Concluding remarks}

In this narrative critical literature review the aim was to answer why microfinance institutions (MFIs) have failed to address poverty, i.e. failed to provide good results in terms of their social performance goal ( called 'outreach' in microfinance literature). So far, several studies of corporate governance literature that show mixed and inconsistent results of MFIs' organizational performances have been carried out (Mersland, 2011; Hudon, 2010; Hartarska and Mersland, 2012; Hartarska, 2005; Mersland and Strom, 2009; Kyereboah-Coleman and Osei, 2008). MFIs are different from most other organizations since they are intended both to provide financial performance and social performance (outreach). To understand how and why MFIs are not reaching their social performance goal properly, another branch of literature is suggested for examination: gender literature may better explain the nature of MFIs' performances and further research on the issue is encouraged.

This critical review has its limitations. No comprehensive review of the literature on gender in general would be possible here, as it would be too broad. At the same time the combined literature on gender and microfinance consists of a few studies only.

The implications of this work should be of relevance to policymakers and academics. Policymakers should now be aware that MFIs should be examined in relation to gender, as women are after all the majority of their clients. Access to finance from MFIs promotes gender equality, particularly in the developing world where these institutions are located. Furthermore, academics are encouraged to research MFIs in relation to gender. They can carry out research by drawing on the vast literature on gender. Although future research could potentially improve our understanding of MFIs, why and when MFIs will successfully address their outreach goal, to reduce poverty, remains an open question.

\section{Bibliography}

Acker, J. (1990). Hierarchies, Jobs, Bodies: A theory of gendered organizations. Gender and Society, 4(2), 139-158.

Adams, R. \& Ferreira, D. (2009). Women in the boardroom and their impact on governance and performance. Journal of Financial Economics, 94, 291-309.

Adams, D.W., Graham, D.H. \& Von Pischke, J.D. (1984). Undermining rural development with cheap credit. Economic Development Institute (Washington, D.C.).Westview Press.

Adams, R. \& Mehran, H. (2012). Bank board structure and performance: Evidence for large bank holding companies. J. Finan. Intermediation, 21, 243-267.

Aguilera, R.V. \& Jackson, G. (2003). The cross-national diversity of corporate governance: Dimensions and determinants. The Academy of Management Review, 28(3), 447-465.

Agier, I. \& Szafarz, A. (2013). Microfinance and gender: Is there a glass ceiling on loan size? World Development. 42, 165-181.

Ahlin, C., Lin, J. \& Maio, M. (2011). Where does microfinance flourish? Microfinance in- 
stitution performance in macroeconomic context. Journal of Development Economics. 95, 105-120.

Armendáriz, B. \& Morduch, J. (2007). The Economics of Microfinance - Second Edition. The MIT Press: Cambridge. Massachusetts. USA.

Assefa, E., Hermes, M \& Meesters, A. (2013). Competition and the performance of microfinance institutions. Applied Financial Economics. 23(9), 767-782.

Augustine, D. (2012). Good practice in corporate governance: Transparency, trust, and performance in the microfinance industry. Business \& Society, 1-18.

Ayayi, G.A. (2012). Credit risk assessment in the microfinance industry. Economics of Transition, 20(1), 37-72.

Barber, B.M., \& Odean, T. (2001). Boys will be boys: Gender, overconfidence, and common stock investment. Q.J. Econ, 116(1), 261-292.

Bassem, B.S. (2009). Governance and performance of microfinance institutions in Mediterranean countries. Journal of Business Economics and Management, 10(1), 31-43.

Beisland, L.A. \& Mersland, R. (2012). An analysis of the drivers of microfinance rating assessment. Nonprofit and Voluntary Sector Quarterly, 1-19.

Bohren, O. \& Strom, R.O. (2010). Governance and politics: Regulating independence and diversity in the boardroom. Journal of Business Finance \& Accounting, 37(9) \& (10), 12811308.

Campbell, K. \& Mínguez-Vera. (2008). Gender diversity in the boardroom and firm financial performance. Journal of Business Ethics, 83, 435-451.

Campion, A. (1998). Current governance practices of microfinance institutions - A survey summary. MicroFinance Network.

Chapple, L. \& Humphrey, J.E. (2014). Does board gender diversity have a financial impact? Evidence using stock portfolio performance. J Bus Ethics, 122, 709-723.

Carter, D.A., Simkins, B.J. \& Simpson, W.G. (2003). Corporate governance, Board diversity, and firm value. The Financial Review, 38, 33-53.

Carter, D.A., D'Souza. F., Simkins, B.J. \& Simpson, W.G. (2010). The gender and ethnic diversity of US boards and board committees and firm financial performance. Corporate Governance: An International Review, 18(5), 396-414.

Cull, R., Demirguc-Kunt, A. \& Morduch, J. (2007). Financial performance and outreach: A global analysis of leading microbanks. The Economic Journal, 117, 107-133.

Coates, J.M., Gurnell, M., \& Sarnyai, Z. (2010). From molecule to market: Steroid hormones and financial risk-taking, Philosophical Transaction of the Royal Society: Biological Science, 365(1538), 331-343.

D’Espallier, B., Guerin, I. \& Mersland, R. (2013). Focus on women in microfinance institutions, The Journal of Development Studies, 49(5), 589-608.

D'Espallier, B. \& Vanroose, A. (2013). Do microfinance institutions accomplish their mission? Evidence from the relationship between traditional financial sector development and microfinance institutions' outreach and performance, Applied Economics, 45, 19651982.

Daily, C.M., Dalton, D.R. \& Cannella, Jr,AA. (2003). Corporate governance: Decades of dialogue and data. The Academy of Management Review, 28(3), 371-382.

Dalton, D.R., Daily, C.M., Ellstrand, A.E. \& Johnson, J.L. (1998). Meta-analytic reviews of board composition, leadership structure, and financial performance. Strategic Management Journal, 19, 269-290.

Dohmen, T., Falk, A., Huffman, D., Sunde, U., Schupp, J., \& Wagner, G.G. (2011). Individual risk attitudes: Measurement, determinants, and behavioral consequences. Journal of the European Economic Association, 9(3), 522-550. 
Dwyer, S., Richard, O.C. \& Cadwick, K. (2003). Gender diversity in management and firm performance: The influence of growth orientation and organizational culture. Journal of Business Research, 56, 1009-1019.

Eagly, A.H. (1987). Sex differences in social behavior: A social-role interpretation. Lawrence Elbaum Associate Publishers. Hillsdale.

Eagly, A.H. \& Johannesen-Schmidt, M. C. (2001). The leadership styles of women and men. Journal of Social Issues, 57(4), 781-797.

Eagly, A. \& Wood, W. (1991). Explaining sex difference in social behavior: A meta-analytic perspective. Personality and Social Psychology Bulletin, 17(3), 306-315.

Eagly, A., Wood, W. \& Diekman, A.B. (2000). Social role theory of sex differences and similarities: A current appraisal. The developmental social psychology of gender, 123-174.

Eckel, C.C., \& Grossman, P.J. (2008). Chapter 113 Men, women and risk aversion: Experimental Evidence. Handbook of Experimental Economics Results, 1, 1061-1073.

Erhardt, N.L., Werbel, J.D. \& Shrader, C.B. (2003). Board of director diversity and firm financial performance. Corporate Governance, 11(2), 102-111.

Eisenhardt, K.M. (1985). Control: Organizational and Economic Approaches. Management Science, 31(2), 134-149.

Fama, E.F. \& Jensen, M.C. (1983). Separation of ownership and control. Journal of Law and Economics, 26(2), 301-325.

Galema, R., Lensink, R. \& Mersland, R. (2012). Do powerful CEOs determine microfinance performance? Journal of Management Studies, 49.

Guiérrez-Goiria, J. \& Goitisolo, B. (2011). Profitability and social performance of microfinance institutions: Empirical evidence of relations between different type of variables. Working paper. 1-23.

Hart, C. (2001). Doing a literature search. London, Sage.

Hartaska, V. (2005). Governance and performance of microfinance institutions in Central and Eastern Europe and the newly independent states. World Development, 33(10), 16271643.

Hartarska, V. \& Mersland, R. (2012). Which governance mechanisms promote efficiency in reaching poor clients? Evidence from rated microfinance institutions. European Financial Management, 18(2), 218-239.

Hartarska, V. \& Nadolnyak, D. (2007). Does regulated microfinance institutions achieve better sustainability and outreach? Cross-country evidence. Applied Economics, 39, $1207-$ 1222.

Hartog, J., Ferrer-i-Carbonell, A., \& Jonker, N. (2002). Linking measured risk aversion to individual characteristics. KYKLOS, 55(1), 3-26.

Hermes, N., Lensink, R. \& Meesters, A. (2011). Outreach and efficiency of microfinance institutions. World Development, 39(6), 938-948.

Hudon, M. (2010). Management of microfinance institutions: Does subsidize matter? Journal of International Development, 22, 890-905.

Jensen, M. \& Meckling, W.H. (1976). Theory of the firm: Managerial behavior, agency costs and ownership structure. Journal of Financial Economics, 3(4), 305-360.

Jesson, J. \& Lacey, F. (2006). How to do (or not to do) a critical literature review. Pharmacy Education, 6(2), 139-148.

Kahan, D.M., Braman, D., Gastil, J., Slovic, P., \& Mertz, C.K. (2007). Culture and identity - protective cognition: Explaining the white-male effect in risk perception. Journal of Empirical Legal Studies, 4(3), 465-505.

Kanter, R.M. (1977). Some effects of proportions on group life: Skewed res ratios and responses to token women. American Journal of Sociology, 82(5), 37-54. 
Karlan, D. \& Goldberg, N. (2011). Microfinance Evaluation Strategies: Notes on Methodology and Findings. The Handbook of Microfinance. Worlds Scientific Publishing Co. Pte. Ltd.

Krishnan, H.A. \& Park, D. (2005). A few good women-on top management teams. Journal of Business Research, 58, 1712-1720.

Kyereboah-Coleman, A \& Osei, K.A. (2008). Outreach and profitability of microfinance institutions: The role of governance. Journal of Economic Studies, 35(3).

Labie, M. (2001). Corporate governance in microfinance organizations: A long and winding road. Management Decision, 39(4): 296-301.

Lascelles, D. \& Mendelson, S. Microfinance Banana Skin (2012). The Centre for the Study of Financial Innovation.

Maes, J..P. \& Reed, L.R. (2012). State of the microcredit summit campaign report 2012. Microcredit Summit Campaign.

Makame, A.H. (2006). Empirical findings on cognitive dissonance around microfinance outreach and sustainability. Working paper. 1-61.

Marmaros, D., \& Sacerdote, B. (2002). Peer and social networks in job search. European Economic Review, 46(4-5), 870-879.

Mengoli, S., Odorici, V., \& Gudjonsson, S. The scorpion who stings the dog who bites: The effect on women's different job positions on gender discrimination in Microfinance. Journal of Research in Gender Studies, 7(1), 137-165.

Mersland, R. (2008). The cost of ownership in microfinance organizations. World Development, 37(2), 469-478.

Mersland, R. (2011). The governance of non-profit microfinance institutions: Lesson from history. J. Mang Gov. 15, 327-348.

Mersland, R. \& Labie, M. (2011). Corporate Governance Challenges in Microfinance. The Handbook of Microfinance, Worlds Scientific Publishing Co. Pte. Ltd.

Mersland, R. \& Strom, R.O. (2008). Performance and trade-offs in microfinance organizations - Does ownership matter? J. Int. Dev. 20, 598-612.

Mersland, R. \& Strom, R.O. (2009). Performance and governance in microfinance institutions. Journal of Banking \& Finance, 33, 662-669.

Mersland, R. \& Strom, O. (2011). The impact of international influence on microbanks' performance: A global survey. International Business Review, 20(2), 163-176.

Mersland, R.\& Urgeghe, L. (2013). International debt financing and performance of microfinance institutions. Strat. Change, 22, 17-29.

Nelson, J. (2014). Are women really more risk-averse than men? A re-analysis of the literature using expanded methods. Journal of Economic Surveys, 29(3), 566-585.

Nielsen, H. \& Huse, M. (2010). The contribution of women on boards of directors: Going beyond the surface. Corporate Governance: An International Review, 18(2), 136-148.

Olivares-Polanco, F. (2005). Commercializing microfinance and deepening outreach? Journal of Microfinance, 7(2).

Olsen, R.A., \& Cox, C.C. (2001). The influence of gender on the perception and response to investment risk: The case of professional investors. Journal of Psychology and Financial Markets, 2(1), 29-36.

Omri, W. \& Chkoundali, R. (2011). The convergence between outreach and financial performance in Mediterranean MFIs: A panel data analysis. Transition Studies Review, 18, 140-163

Perilleux, A., Hudon, M. \& Bloy, E. (2011). Surplus distribution in microfinance: Difference among cooperative, nonprofit, and shareholder forms of ownership. Nonprofit and Voluntary Sector Quarterly, 41(3), 386-404. 
Powell, M., \& Ansic, D. (1997). Gender differences in risk behavior in financial decision making. Journal of Economic Psychology, 18, 605-628.

Quayes, S. (2012). Depth of outreach and financial sustainability of microfinance institutions. Applied Economics, 44, 3421-3433.

Renneboog, L., Horst, J.T. \& Zhang, C. (2008). Socially responsible investments: Institutional aspects, performance and investor behavior. Journal of Banking $\mathcal{E}$ Finance, 32: 17231742.

Rock, R., Otero, M. \& Saltzman, S. (1998). Principles and practices of microfinance governance. Microenterprise Best Practices, ACCION International.

Sapienza, P., Zingales, L., \& Maestripieri, D. (2009). Gender difference in financial risk aversion and career choices are affected by testosterone. PNAS 106, (36), 15268-73.

Shrader, C.B., Blackburn, B.V. \& Iles, P. (1997). Women in management and firm financial performance: An exploratory study. Journal of Managerial Issues, 9(3), 355-372.

Smith, N., Smith, V. \& Verner, M. (2006). Do women in top management affect firm performance? A panel study of 2,500 Danish firms. International Journal of Productivity and Performance Management, 55(7), 569-593.

Strom, R.O., D'Espallier, B. \& Merlsand, R. (2014). Female leadership, performance, and governance in microfinance institutions. Journal of Banking $\mathcal{E}$ Finance, 42, 60-75.

Yao, R., \& Hanna, S. (2005). The effect of gender and marital status on financial risk tolerance. Journal of Personal Finance, 68-85.

Yunus, M. (2007). Banker to the poor, micro-lending and the battle against world poverty. PublicAffairs. USA.

Vanroose, A. (2008). What macro factors make microfinance institutions reach out? Saving and Development, 32(3), 153-174.

Williamson, O.E. (1985). The Economic Institutions of Capitalism; Firms, Markets, Relational Contracting., Reprinted from the English Edition by The Free Press, a Division of Macmillan Inc.

World Bank. (2012). The Little Data Book on Financial Inclusion. The International Bank for Reconstruction and Development / The World Bank. 